УДК 378.4

\title{
Training Platform: The Network of Best Language Teaching Practices Sharing
}

\author{
Elena G. Tareva* \\ Moscow City Pedagogical University \\ 5 b Maly Kazenny per., Moscow, 105064, Russia
}

Received 30.08.2015, received in revised form 17.09.2015, accepted 31.10.2015

\begin{abstract}
The article represents an innovative model of accumulation and promotion of best practices of foreign language teaching in the system of lifelong learning. It gives the idea about the nature, status, and features of language teaching practices as a new didactic phenomenon. The author describes the functions and justifies the role of a training platform as a form of exchange of best practices of teaching foreign languages. The research provides the analysis of positive aspects of training platforms as special forms of cooperation between teachers in the sphere of teaching foreign languages with the purpose of sharing best practices. Alongside with that the paper lists the unrealized potential of the platforms, the implementation of which will improve the quality of foreign language teaching within LLL.
\end{abstract}

Keywords: training platform, educational practices, best language teaching practices, lifelong learning, innovations in language teaching.

The article is written with the financial support of the European Commission within the Tempus IV programme (Project "Lifelong Language Learning University Centre Network for New Career Opportunities and Personal Development (UNICO)”, № 544283-TEMPUS-1-2013-1-ES-TEMPUSJPHES).

DOI: 10.17516/1997-1370-2015-8-11-2677-2683.

Research area: pedagogy.

\section{Language teaching: new challenges in the era of lifelong learning (Instead of Introduction)}

During the period of drastic change of educational needs we witness the appearance and development of «lifelong learning» (LLL) strategy, which marked the revolutionary changes in the sphere of training and education of an individual who is ready for permanent changes in his environment, able to adapt quickly to unpredictable transformations of his living space. Intensive processes of information saturation and spread that can be described as information revolution in the development of the society are the direct consequences of globalization, and the modern world community is becoming global. The main condition for functioning of such a society is a global business network (as a new form of communication) that ignores state borders (Castells, 2000).

(C) Siberian Federal University. All rights reserved

* Corresponding author E-mail address: elenatareva@mail.ru 
Such trends change both the nature of communication and the requirements to the individuality of a communicant. We see the formation of a «super-text» and «meta-language», for the first time in the history uniting in one system the written, oral, and audiovisual means of human communication (Castells, 2000). This method of communication helps people adapt to the situation of geographical and professional mobility, which requires a great professional and communicative flexibility. It will improve the level of education and the level of professional skills due to implementation of individual routes on the formal, informal, and non-formal levels of educational system.

Thus, the concept of lifelong learning is not aimed at the formation of a set of certain qualities of a given learner, but at the comprehensive development of his personal potential in the variable, multi-level educational environment, at the permanent acquiring of new competencies in order to meet the challenges of a dynamic, unstable society. The guide in the world of continuous self-development is the ability to communicate especially in cross-cultural environment. This ability allows the perfection of an individuality regardless borders, national barriers, and cultural stereotypes. The communicative aspect of LLL serves as a «controller» of the activity and cognitive processes as well as the overall success of a person throughout his life.

Therefore, the priority is given to the dissemination of positive experience of foreign language teaching, contribution to development of which has been made by many generations of scientists, educators, and practitioners. The LLL needs a network exchange of best practices of foreign language teaching. The level of realization of this exchange will affect the very opportunity of implementation of the idea of such education, as well as the formation of an individuality of the new era.

\section{The best language teaching practices: qualification and classification}

Educational practices is a relatively new term, but it has been widely used recently in scientific publications, which are devoted to modernization of the national educational system. The frequency of its use is explained by the desire to strengthen the practical orientation of the educational system, to emphasize originality of its modern, innovative character by adding it to the traditional categories such as «educational technology», «educational models», «educational strategies», «pedagogical practice», «teacher's practice», «the practice of school / college», «the practice of the Ministry of Education», «practice of teaching of the subject».

The best educational practice should be viewed as positive (leading to qualitative changes) innovative teaching experience, containing educational precedents, which are based on the authors' concepts of organization of educational process targeted at changes of educational reality (Tareva, 2015). This interpretation makes it possible to include this concept in terminology of General Didactics and Specific Didactics, for example, Language Teaching, which is experiencing today the need for a qualitative renovation due to practical orientation of foreign language education, oriented at the formation of an individual who is ready for self-development and participation in cross-cultural communication. Consequently, the best language teaching practice is a positive (leading to a qualitative transformation) innovative experience of foreign language teaching (in secondary school and University), containing precedents in the field of foreign language teaching, which are based on the authors' concepts of organization of educational process targeted at changes in foreign language education.

Best practice is different from the unconscious, intuitive educational activity by the 
presence of reflexive design - technological and / or theoretical description aimed at translation to stakeholders. The signs, which allow to differentiate language teaching practices from the related phenomena, include the following indicators:

- language teaching practice is obligatory related to innovations in foreign language education;

- language teaching practice fixes the fact of «personal presence» of its developer in the foreign language education - the author, group of authors; the practice is designed to remove a certain kind of «anonymity» of positive (productive) educational achievements in the sphere of foreign language teaching;

- there must be confirmed the fact of compulsory implementation and social recognition of language teaching practice; as a «best» can be recognized only the practice which is widely advertised, presented and justified in various publications and discussions (e.g., conferences, debates and so on);

- language teaching practices deal with changes in the quality of foreign language teaching and the ways of interaction between participants of the language learning and language teaching process; as the best may be recognized only those practices that fit into the modern personality-oriented concept of foreign language education and which are based on productive interaction (dialogue) between teacher and learner;

- language teaching practice must be «validated»; the following formula is proposed: the initiative (need + motive), a person (team) $\rightarrow$ localization (the venue) $\rightarrow$ activities to promote practices $\rightarrow$ productivity (the effect of the positive impact on the educational context).

The greatest difficulty in understanding and describing the language teaching practices happens due to their diversity and the consequent complexity of their counting, enumeration, grouping, classification, differentiation, and so on. There is a large number of non-conventional (a kind of «illegal»), non-formalized, nonsystematic (other than the universally recognized ones) language teaching practices. In the case of positive evolution and public acceptance a teaching practice is approved as standard, it loses its veil of irrationality, changes its status from a subjective («useful for me»), to objective («useful for all»).

Among positive «effects» of practices the following indicators should be highlighted:

- change of the subject of the educational activity: from the subject who is the beginner in the acquisition of new areas of experience to the subject, whose expertise is applied for acquisition of the new; from the subject learning to the subject acting / transforming; from individual subject to the collective one;

- change in the interaction from teaching / educating mode to the subject-subject, dialogical mode;

- change of goal-setting: from mentoring to transformative, contextual (including professional context), managerial;

- refocusing of education from teaching and learning procedure - to informative and practical mode, informative and transformative orientation and to practical outcomes of education;

- change in the nature of teaching from traditional - to interactive education based on proper experience;

- change of the sources of teaching and learning: from provision of information - 
to really practical, transformative (working, vital) experience of the participants, their real problems;

- change in the assessment of outcomes: from assessment of learning outcomes to assessment of the effect of training on behavior (in professional context competences) as well as practical training of students and the organization including the evaluation of production and financial efficiency of the education;

- change of the role of education in the working environment: from supporting to innovative / transformational;

- change in the role of a mentor (teacher) from the role of an expert to the deep dialogical roles of a facilitator, tutor, coach (Clarín, 2013).

\section{Training platform: potential for lifelong language learning}

A training platform (TP) can serve as a domain within which the best language teaching practices can be collected, classified, and described. The purpose of this platform is accumulation, generation, and dissemination of best practices of foreign language teaching. This will help to educate the younger generation to participate in intercultural communication. There are several advantages of this innovative model of interaction between the subjects of the educational process. First, the main task of TP is replicating of the successful experience, informing the territories about the initiatives of the federal center in the field of education, the formation of mechanisms of «peers feedback» within local and all-Russian educational communities. Second, TP is a platform to develop a nationwide pool of leading consultants in the sphere of development of the educational system. Third, TP has confirmed its status as an innovative model of training teachers and senior educational managers as well as the practice of a personalized form of retraining. Fourth, the activities of all TP are united by the idea of dissemination of relevant and significant experience of successful activity through (a) the variety of content, forms, methods and technologies of teaching and education of the younger generation through creative potential of teachers; (b) individualization of methods of teaching and education of students; (c) an active interdepartmental and networking interaction. Finally, fifth, TP forms a new quality of educational space, educational environment.

Alongside with the positive results of the organization of the TP there are some unrealized possibilities of this innovative system, such as:

1) the existing TP are narrowly focused in terms of solving current problems: implementation of National Curriculum, improvement of preschool educational institutions and so on;

2) from the point of the scale the activity of platforms is usually aimed at one level of the educational system (either pre-school or secondary education);

3) as a rule TP operate within the system of professional development, enriching it with new forms of interaction with participants-trainees;

4) there is no experience of dissemination of innovations (best practices) from the point of view of application of best practices to foreign language communication teaching;

5) according to the strategy of $\mathrm{TP}$ organization they operate with traditional forms of interaction with trainees: lectures, workshops and seminars, round tables, and so forth. There are no innovative forms, based on the potential of the Internet environment, providing the scale and interactivity of interaction among TP participants: interns, authors of best practices, experts, tutors and others.

TP can become a leading center for the integration of efforts of teachers of 
foreign languages, being able to accumulate and disseminate experience of design and implementation of best practices of foreign language teaching. It can also serve as a virtual center for a wide language teaching community, able to improve the quality of teaching younger generation to participate in the intercultural dialogue. So, the TP must perform the following functions:

- educational functions: design and implementation of training programs at various levels, creation of conditions for understanding of the essence, advantages, areas of dissemination of best language teaching practices; creation of conditions for the development of designing and research competence of trainees; development of virtual educational space for interactive work with trainees, etc.;

- methodological functions: accumulation, analysis and promotion of educational and methodological documentation, professional and educational standards of teachers / teachers of foreign languages training; consultancy and expertise of best language teaching practices; scientific and methodological support of trainees, including assistance in carrying out the work, reinforcement of trainees' initiatives (action on the principle of «mastering practices create own practices»); establishment of contacts, networking; organization and holding of round tables, methodological seminars, conferences and workshops, including those in electronic and telecommunication formats; participation in innovative projects, translation of best experience, etc.;

- organizationalfunctions: the development of the local regulatory framework of educational and scientific cooperation on the basis of a network of educational institutions; registration of trainees (creation of database), groups of experts, auditors and others;

- marketing functions: participation in marketing research of the city resources, analysis of the needs of potential trainees, the degree of their satisfaction as the result of educational activity of the training platform;

- advertising and educational functions: creation of conditions for broad announcement of training platform's functions, prompt notification of all stakeholders about the peculiarities of its activity;

- the function of intercultural integration: interaction of participants of the training platform with foreign partners - the leading scientists in the field of language teaching and educational practices.

To perform its functions the activity of TP should be aimed at achieving the following objectives:

- creation of conditions for organization of educational space, expanding the possibility of dissemination of best practices of teaching foreign languages in order to improve the quality of teaching students to participate in cross-cultural communication;

- accumulation in the Internet space of foreign language teaching practices, their classification, and certification aimed at improvement of the operationality of their testing, implementation in different conditions of younger generation education (schoolchildren and students) for cross-cultural communication;

- creation and promotion of the electronic portal as an Internet continuum of foreign language teaching practices - constantly 
maintained and updated virtual environment for best practices of foreign language teaching;

- promotion ofimplementation of innovative experience of teaching foreign languages in the educational practices of teachers, professors, undergraduate, graduate and post-graduate students (hereinafter - the trainees);

- development and improvement of professional competencies of trainees, creation of conditions for designing on their own experience of innovative alternative models (practices) of professional activities that are adapted to the specific conditions of the educational institution;

- creation of the atmosphere of open exchange of the results of the application of the best foreign language teaching practices in different educational contexts while training, retraining and advanced training of foreign language teachers;

- creation of the conditions for organization of networking among educational institutions of various levels to provide vertical and horizontal integration in the process of reviewing, implementation and evaluation of the best foreign language teaching practices;

- dissemination of the most important theoretical concepts underlying the creation and dissemination of innovative foreign language teaching practices; scientific and educational activities among teachers, foreign language professors, undergraduate, graduate, post-graduate students.

In the system of LLL TP play an important role. At the level of formal education training platform is designed for teachers, experts, facilitators, tutors with further issuance of a diploma / certificate of completion of education. At the level of non-formal education TP become the network for people with common interests in innovations at educational practices. In the context of informal education TP is designed to provide personal promotion of a student (trainee) on the way of perception of the best educational practices and lead to the formation of individual educational routes (private consultation, individual interviews and so forth), to satisfaction of their personal needs, expanding of the sphere of individual keenness (hobbies) and so on.

\section{Conclusion}

In place of the intuitive impulses and fictions of perestroika time which were driven by hostility of the recent past, rather than the study of certain positive goals, come conscious, verified, tested, and positivelyproven innovative educational practices. Their generation is carried out not in the space of ideas and not just in the space of actions of an individual subject; practice becomes truly innovative only when it acquires cultural sense, when innovative experience of such activities is made available to others. This involves fixing of innovative experience, its cultural shaping, and translation mechanisms.

A training platform can become such a mechanism, being regarded as a factor and a resource of an upgrade and improvement of the quality of foreign language education, bettering the level of professional training of teachers, as a center for integration of scientific achievements and best foreign language practices, as a model of personal innovation activity of each foreign language teacher, as a way of implementing LLL in the teaching community. A TP may be seen as an «incubator» which not only «breeds» best foreign language teaching practices, but also forms the community (a network of) teachers / 
teachers of foreign languages who are ready to solve problems of improvement of the quality of foreign language education through collective actions.

\title{
References
}

Castells, M. Informacionnaja jepoha: Jekonomika, obshhestvo i kul'tura [Information Epoch: Economy, Society, and Culture]. Moscow, SU HSE, 2000. 608 p.

Clarín, M.V. Innovacionnye tendencii razvitija korporativnogo obrazovanija. Innovacionnoe razvitie obrazovatel'nyh programm nepreryvnogo obrazovanija: metodologija i praktika [Innovation Tendencies of the Development of Corporate Education]. V.A. Ermolenko (ed.). Moscow, The Institute of Theory and History of Didactics RAE, 2013. P. 53-107.

Tareva, E.G. (2015) Razvitie lingvoobrazovatel'nyh praktik: optimistichnaja proekcija [Evolution of Foreign Language Teaching Practices: Optimistic Projection]. Vestnik Moskovskogo gorodskogo pedagogicheskogo universiteta. Filologija. Teorija jazyka. Jazykovoe obrazovanie. № 2(18), 75-85.

\section{Стажировочная площадка \\ как форма сетевого обмена передовыми \\ лингвообразовательными практиками}

\author{
Е.Г. Тарева \\ Московский городской педагогический университет \\ Россия, 129226, Москва, Малыій Казенный пер., 56
}

\begin{abstract}
B статье речь идет об инновационной модели аккумуляции и продвижения передовых практик обучения иностранным языкам в системе непрерывного образования. Дается представление о сущности, статусе и особенностях передовых лингвообразовательных практик как новом дидактическом феномене. Представляются ориентиры, описываются функиии и обосновывается назначение стажировочной площадки как формы обмена передовыми практиками обучения иностранным языкам. Автор приводит анализ положительных сторон стажировочных площадок как особых форм взаимодействия педагогических кадров в сфере обучения иностранным языкам с иелью обмена передовым опытом. Одновременно перечисляются нереализованные возможности площяаок, реализачия которых обеспечит повышение качества обучения иностранным языкам в области непрерывного образования (LLL).
\end{abstract}

Ключевые слова: стажировочная площадка, образовательные практики, передовые практики обучения иностранным языкам, lifelong learning, инновации в иноязычном образовании.

Статья написана при финансовой поддержке гранта программы ТЕМПУС IV Европейского Союза (проект «Создание сети университетских языковых иентров для профессионального и личностного развития человека в рамках парадигмы «образование в течение всей жизни», № 544283-TEMPUS-1-2013-1-ES-TEMPUS-JPHES).

Научная специальность: 13.00.00 - педагогические науки. 